\title{
Dissemination activities — Summer 1986
}

The summer of 1986 was characterized by intense activity in the dissemination of knowledge of international humanitarian law and of Red Cross Principles and ideals. Courses and seminars were organized in Strasbourg, Warsaw, Lima, Quito and San José for dissemination officers of National Societies, as well as for law students, judges, representatives of government circles, etc. from Europe and the Americas.

\section{Strasbourg}

The close co-operation between the International Institute of Human Rights in Strasbourg, the ICRC and the Henry Dunant Institute has been reflected since 1973 in the organization of an annual course on international humanitarian law for law students as part of the summer session at the Strasbourg Institute.

This year the ten-hour course was held from 28 July to 1 August and was given simultaneously in English, French and Spanish. The lecturers were Mr. M. Veuthey, Head of the International Organizations Division at the ICRC, Mr. J. Meurant, in his capacity as Director of the Henry Dunant Institute, and Mr. C. Swinarski, ICRC legal adviser. The course was attended by about 200 students.

\section{Warsaw}

The fourth summer course on international humanitarian law for advanced law students from Europe and North America was held in Warsaw from 19 to 30 August. The course, organized by the Polish Red Cross and the ICRC, was opened by Professor J. Bonczak, 
President of the Polish Red Cross, and Mr. M. Aubert, VicePresident of the ICRC. University lecturers from France, Great Britain, Italy, Poland, the United States and the USSR, as well as Mrs. C. Kruck, Mr. J. Meurant, Mr. J. Sassoli and Mr. M. Veuthey, all from the ICRC, gave lectures on international humanitarian law to 36 students and examined with them the ways of promoting knowledge of this law in their respective countries.

\section{Lima}

The second training course for persons in charge of dissemination in South American National Societies took place in Lima from 11 to 16 August. This training course, the fifth to have been organized in Latin America and the second in South America since 1983, brought together 24 participants from eight South American National Societies and, as special guests, representatives of two National Societies from Central America.

Such courses, organized by the ICRC in co-operation with the League and a National Society-in this case the Peruvian Red Cross-are intended for National Society officers directly involved in dissemination activities. The topics (history of the Red Cross, International Red Cross, Principles, emblem, doctrine, international humanitarian law) are dealt with from the viewpoint of a National Society working in situations of armed conflict or internal disturbances or tensions.

The method used is based on active and constant participation by all delegates, who are divided into small working groups with the task of working out solutions to practical exercises. This makes it possible to gain a better insight into the problems facing National Societies.

The ultimate aim of these courses is to establish a permanent structure and clearly defined tasks within National Societies for their dissemination work, and to train dissemination officers.

The ICRC was represented by Mr. R. Hammer, dissemination delegate for Latin America, as well as by several regional delegates, while the League was represented by Mrs. A. Baccino, delegate.

\section{Quito}

The Round Table on the safety of journalists on dangerous professional missions, held in April 1985 at Mont Pèlerin sur Vevey 
(Switzerland), had recommended that the ICRC organize regional seminars to promote knowledge of its activities among journalists (see summary in International Review of the Red Cross, No. 246, May-June 1985, pp. 184-186).

The Latin American seminar "Media and international humanitarian law", organized by the ICRC in co-operation with the Ecuadorean Red Cross and held in Quito from 18 to 21 August, was a follow-up to that Round Table.

Thirty-three journalists and various media representatives from 17 Latin American countries took part in this seminar, whose main topic was the protection of journalists on dangerous missions. The organizers wished, however, to broaden the debate in order to make media circles, which play a very important role in forming public opinion, more familiar with the work of the ICRC.

A more detailed presentation of humanitarian law made it possible above all to put emphasis on the distinction between international and non-international armed conflict and on the inapplicability of humanitarian law in internal disturbances or tensions, as well as on the difference between international humanitarian law and human rights, which are all subjects of direct everyday concern to journalists.

An exposé on ICRC operations in Latin America and throughout the world was followed by a presentation of the bases, and hence the scope and restrictions, of the ICRC's humanitarian action. This subject is quite a delicate one, in that the ICRC's and the journalists' goals do not always coincide: whereas the ICRC is bound to respect the principles of neutrality and impartiality and thus be discreet about its activities in the interest of the victims, journalists seek to obtain maximum information and to pass it all on, invoking the public's right to know.

One of the main objectives of the seminar was to promote understanding and acceptance of the specific nature of ICRC action. Judging from the journalists' reactions, that goal was achieved. The account of an ICRC delegate's visit, by one of the participants who had spent 13 years in detention, certainly contributed towards that comprehension.

The participants expressed the hope that in future the ICRC would also organize national seminars. The ICRC's task will now be to foster the contacts established at this seminar, so as to ensure wider coverage of its activities in the field and to be able to count on the support of the mass media in its dissemination programmes. 
The ICRC delegation was made up of Mr. R. Hammer, dissemination delegate for Latin America, several ICRC staff members and regional delegates.

\section{San José}

The ICRC took part in the fourth interdisciplinary course which is organized every year by the Inter-American Institute of Human Rights in San José (Costa Rica).

International humanitarian law has been taught at the Institute since 1985, when the ICRC founded "the Jean Pictet chair of international humanitarian law".

The course, held from 17 to 30 August, was attended by 182 participants representing governments, the judiciary, universities and national non-governmental human rights organizations from all the countries in the Americas.

The ICRC was represented by Mr. C. Swinarski, legal adviser.

\section{Mexico one year after the earthquake}

On 19 September 1985 Mexico City and the provinces along the Pacific coast were hit by a strong earthquake which left over 5,000 people dead and hundreds of thousands homeless. The rehousing of survivors was and remains the most imperative problem, since almost 100,000 persons are still living in temporary shelters.

After the earthquake, the League of Red Cross and Red Crescent Societies received about 54 million Swiss francs in cash and in kind from National Societies and governments. Red Cross relief operations began immediately after the disaster, distributing thousands of tonnes of relief supplies for a total value of 8.5 million Swiss francs.

Operations are still continuing, but today the accent is on rehabilitation and reconstruction. More than 2,000 houses have been built in the States of Guerrero and Jalisco, as well as in the Federal District. Priority is given to housing in rural areas to stop families flocking to urban centres and aggravating already existing problems. 